\title{
CABle Laying and Pulling
}

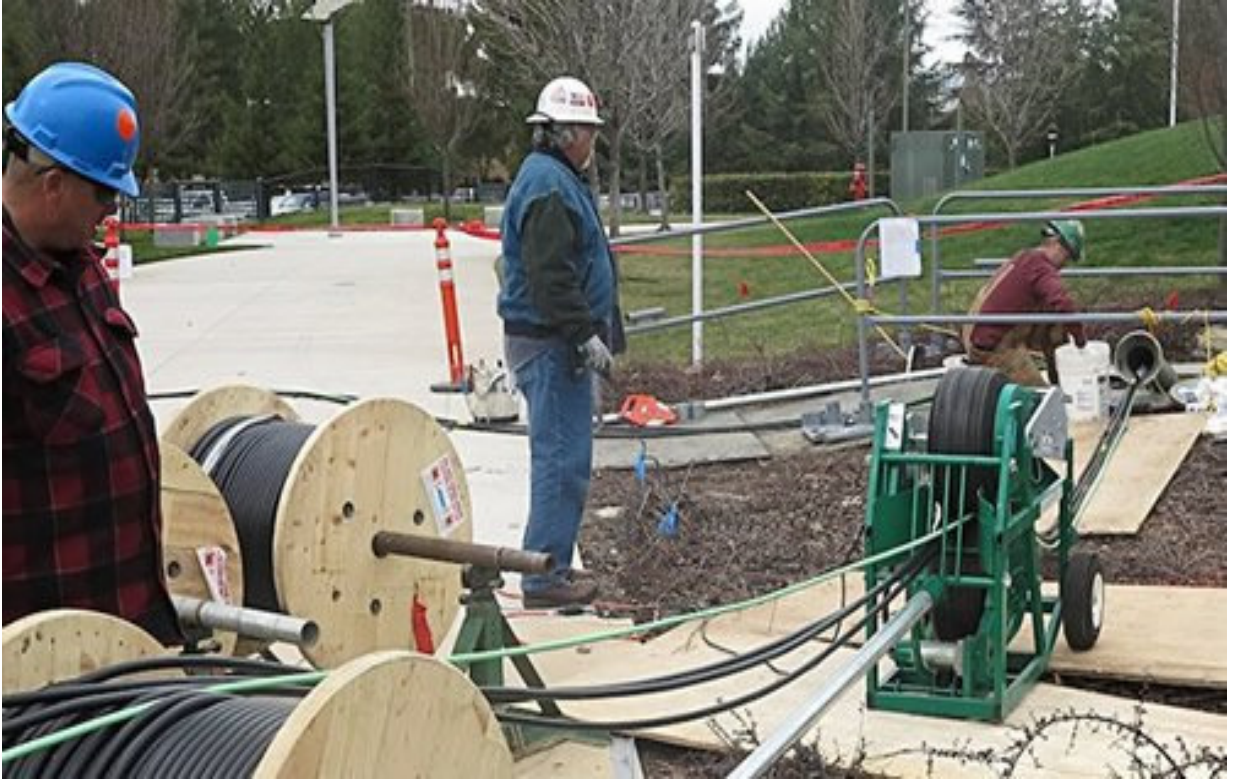

1. General

The common methods of cable laying are:

- Direct in the ground in trenches (underground cables).

- In cable trenches in outdoors switchyards.

- In cable trays or cable ducts

- Fixed with clamps (usually at walls and ceilings).

- In conduits

\section{Cable laying arrangement}

Multicore cables are laid in "flat formation" arrangement and single core cables may be laid in "trefoil" arrangement or in "flat formation" arrangement.

For single core cables "trefoil" arrangement is the most advised method.

\section{Segregation of cables}

No matter what method is used for laying, cables must be segregate taking into account the voltage level and function, in order to avoid possible electromagnetic interferences that can disturb the networks and the signals cables are carrying on.

Segregation means that cables with different voltage levels and/or different functions must not be laid at the same physical support and must be separated.

Segregation of cables must be done in accordance with standards and regulations, as well as local authorities' recommendations and must consider the following situations:

- Power cables (by voltage level);

- Control cables;

- Communication cables.

\section{Cable marking}

Cables must be identified along cable runs, using cable markers or labels, showing the reference of each cable.

This identification shall be according to the following 
principles:

- $\quad$ Every $150 \mathrm{~m}$;

- $\quad$ Changes in direction;

- Both ends.

For underground cables splices must be marked and along the cable run wood or concrete markers shall be installed to identify cable run.

\section{Cable laying}

Cables for power transmission and distribution networks and cables for major communications networks within city areas are usually installed in trenches, directly buried in the ground.

In most countries LV and MV distribution networks, mainly in rural areas, are overhead lines. Also HV transmission networks are overhead lines. However overhead lines present some disadvantages:

- However overhead lines present some disadvantages:

- Occupy more area;

- Have more visual impact;

- Emanate electric fields that can affect people;

- Are affected by storms, namely lighting phenomena.

By these reasons electrical distribution companies and some electric transmission companies have made an option for underground cables, although it is a more expensive solution.

Underground cables present a set of advantages in relation to overhead lines:

- It provides the missing cross border link to urban or near to rural areas;

- Underground cables are not susceptible to storm damage;
- Underground cables are "invisible", so no visual intrusion;

- Lower losses;

- No electric field emanates from underground cables

- Magnetic field from underground can be managed, by use of trefoil arrangement and shielding.

Underground cables must be mechanically protected power cables are required to be armored - and communications cables must be protected by conduits plastic or metallic.

Also power cables may be protected by plastic conduits, namely when crossing roads and other traffic routes; according to the recommendations of local authorities conduits may be concrete enclosed.

The depth of the trench depends on local regulations and trenches must be provided with a cable tile and a warning tape.

Manholes for inspection shall be provided.

In outdoors switchyards cables are installed in concrete trenches (pre-fabricated or site fabricated) with covers.

These trenches must have drains and a suitable inclination to avoid rain water to accumulate; they also must be provided with metallic supports for cable laying.

Cables may also installed in cable trays.

Cable trays must be chosen according to environmental conditions, like strong chemical corrosion and may be made of:

- Galvanized steel;

- Stainless steel;

- Aluminium;

- Glass-fiber reinforced plastic. 
Cable trays may be provided with a cover and cables must be tight with cable ties.

Cables may also be installed with clamps fixed on ceilings and walls, mainly LV cables.

Mainly in residential installations cables may be installed in conduits (plastic or metallic), usually recessed.

Communications cables usually are installed in conduits, for mechanical protection.

However in industry and in substations it may be required to install power cables in metallic conduits for mechanical protection.

When metallic conduits are used for single core cables, those conduits must be of a non-magnetic material, in order to avoid induced current in the conduit and the consequent heating of the conduit.

\section{Cable pulling}

Cable pulling if it is not done properly may cause damages to

Notas soltas:

Sistema de proteção contra descargas atmosféricas com dispositivo de ionização (SPDI): Sistema completo baseado em um ou mais PDI e todos os elementos necessários para conduzir a corrente da descarga atmosférica à terra com toda a segurança a fim de proteger uma estrutura, um edifício ou uma área aberta contra os impacto diretos das descargas atmosféricas.

Para-raios com dispositivo de ionização (PDI): Para-raios que nas mesmas condições, gera um traçador ascendente de inicialização mais rápido que um para-raios de haste simples.

Terra: Parte de um SPDI, projetado para conduzir e dissipar a corrente da descarga atmosférica no solo. the outer sheath of the cables, this leading, sooner or later, to a fault in the cable.

Pulling tension must be in accordance with the type of cable and the instructions of the manufacturer must be followed.

Also maximum bending radii indicated by the manufacturers must not be excided.

For long runs, when installing cables in trenches and cable trays special equipment and tools must be used:

- Cable pulling winch (mechanical drive)

- Cable feeders for reels;

- Cable rollers;

- Tirfors.

When installing cables in conduits approved lubricants of type compatible with cable jacket must be used to reduce pulling tension.

If more than one cable is to be installed in the same conduit they must be installed simultaneously. A "fish tape" shall be used.

Condutor de baixada: Parte do sistema de proteção contra descargas atmosféricas que se destina a conduzir a corrente da descarga atmosférica do PDI para a terra.

Eficácia do PDI ( $\Delta \mathrm{T})$ : Diferença em microssegundos entre o tempo de emissão do traçador ascendente de um elemento captor PDI e um elemento captor de haste simples (PHS), medido em laboratório sob as condições definidas na presente documento.

Densidade de descargas atmosféricas $(\mathrm{Ng})$ : Número de descargas atmosféricas por km2 por ano. Este valor pode ser obtido a partir da rede local de deteção de descarga atmosférica que atingem o solo. 